\title{
S.E. Wilmer
}

\section{Performing "Polishness"}

\author{
Dariusz Kosiński \\ Performing Poland: Rethinking Histories and Theatres \\ Translated by Paul Vickers \\ (Aberystwyth: Instytut Teatralny and Performance Research Books, 2019)
}

Dariusz Kosiński's Performing Poland: Rethinking Histories and Theatres is an impressive undertaking, introducing several centuries of Polish theatre and performance in a beautifully illustrated 400 -page volume. The book is divided into five sections which overlap chronologically: theatre of festivities, theatre of fundamental questions, national theatre, political theatre, and theatre of the cultural metropolis. These five sections allow Kosiński to investigate various themes that stretch the terminology of theatre and performance into quite wide-ranging areas.

The theatre of festivities explores the Christian calendar of religious festivals such as Nativity, Shrovetide, and Easter celebrations, as well as traditional door-to-door performances and ritualistic types of events and occasions such as weddings and funerals. 
The section on the theatre of fundamental questions, which he also labels the Polish theatre of transformation, concentrates mainly on the nineteenth-century tradition of Romantic dramas, such as those by Adam Mickiewicz, Juliusz Słowacki, Zygmunt Krasiński and Stanisław Wyspiański, and the repercussions of their work in productions by subsequent artists in the twentieth century including Jerzy Grotowski and Tadeusz Kantor. The careers of these four romantic poets are elaborated further in sub-sections called interludes.

The national theatre section considers theatre houses that have been labeled as national theaters, including Wojciech Bogusławski's role as "the founding father of the national stage"' for, amongst other things, preserving the use of the Polish language in theaters from 1791 when Poland was under foreign occupation. The national theatre section also covers theatrical performances that represent national character and identity in major Polish events such as uprisings, often using Aesopian devices to overcome foreign censorship. It also reveals how the National Theatre in Warsaw did not recover artistically following a fire in 1985, and how Kraków's Stary Teatr (old theatre) became the preeminent venue.

The political theatre section examines not only activist drama but also important political performances, demonstrations, and political events, especially during foreign occupations and the communist regime. The last section on theatre of cultural metropolis reviews the theatre history of Poland and demonstrates how certain cities have developed leading theaters or conversely lost their influence over the centuries. It also reveals the success of female actors in the nineteenth century such as Helena Modjeska (who became an international star), and the increasingly dominant position of directors from the beginning of the twentieth century, such as Leon Schiller and Arnold Szyfman, and the importance of twentieth-century playwrights Witold Gombrowicz and Tadeusz Różewicz.

Unlike most national theatre histories which pursue a chronological approach of significant plays, artists and theatrical events, Kosiński’s strategy is more philosophical, emphasizing themes and concepts more than individual works. Rather than giving detailed plot descriptions of significant dramas, Kosiński looks at the underlying messages and meanings behind the dramas and events. As he puts it, "there is greater emphasis here on problems, questions and doubts than on facts, dates and descriptions" (20).

The major works and productions of Mickiewicz, Słowacki, Wyspiański and Krasiński, especially Mickiewicz's Dziady (Forefathers' Eve), Słowacki's Kordian, Wyspiański's The Wedding and Deliverance and Krasiński's The Un-Divine Comedy,

1 Dariusz Kosiński, Performing Poland: Rethinking Histories and Theatres, trans. Paul Vickers (Aberystwyth: Instytut Teatralny and Performance Research Books, 2019), 155. All further quotations from this book are provided in parentheses. 
are discussed in more than one section, as is the work of more modern artists such as Jerzy Grotowski (Akropolis and The Constant Prince) and Tadeusz Kantor (Dead Class and Wielopole, Wielopole). Kosiński shows how performances by Grotowski and Kantor evolved through experimentation over many years, although the descriptions of their individual productions are quite brief. He also introduces such avant-garde theatre companies as Gardzienice, Song of the Goat, and the Theatre of the Eighth Day and important performance artists including Katarzyna Kozyra.

The last section of the book on the cultural metropolis looks at some of the general trends in Polish theatre over the last two centuries and brings the book up to date with recent artistic developments in the productions by Jerzy Grzegorzewski, Jerzy Jarocki, and Krystian Lupa in the late twentieth century, and Lupa's disciples Grzegorz Jarzyna and Krzysztof Warlikowski as well as Jan Klata, and the so-called "new theatre" (with its echoes of the "in yer face theatre" of Great Britain) making novel use of site-specific environments, multimedia effects and violent dramaturgy in the twenty-first century.

Kosiński also indicates the influence of the far-right on Polish theatre since 2010, such as the intimidation that led to the cancellation of Rodrigo Garcia's Golgotha Picnic at the Malta Festival Poznan in 2014, but he obviously did not have the opportunity to comment on the more recent production of Klatwa (The Curse) by Oliver Frljić that caused massive demonstrations and threats against a leading actor in Warsaw in 2017, nor the even more recent Women's Strike protests against new abortion laws in 2020-2021.

Although the book can be read from cover to cover, I would imagine that, given its length and voluminous detail, most readers would want to use it as a resource to find out information about individual artists, productions, plays, and events. For this purpose, it would have been helpful to include an index, especially as the discussion of specific artists and plays appears in more than one section.

A more problematic issue is Kosiński's emphasis throughout the book on the role of theatre and performance in asserting Polish national identity. In the introduction he states:

By presenting the history of Polish performances, I thus focus on what, in my view, is specific to them and which in turn influences the specificity of "Polishness" both as a set of specific attitudes and also as something that is itself performed.... "Being Polish" means above all, I believe, performing or acting in a way that differentiates itself through particular qualities and values that manifest themselves at the level of specific actions, including artistic activities and practices. I do not formulate this thesis, and provide evidence supporting it, in order to suggest that "Polishness" is merely an act; rather, my goal is to indicate the essential traits of a performative mode of existence that guaranteed the survival of the collective while preserving what it considered to be its most important values (18). 
Although Kosiński is quite forthright in admitting that his approach "might arouse suspicion that I am demonstrating some form of nationalism through my theatre history, effacing the performance by the other nationalities coconstitutive of Polish culture" (22), he nevertheless asserts,

I would like to assure readers that adopting the title Performing Poland does not mean that I consider only ethnically and linguistically Polish performances to be significant and worthy of research in respect of the historically contingent whole that we term "Polish culture" (22).

Thus, Kosiński is aware of the problem that he is creating with "the absence of performances by ethnic groups other than Poles" and the lack of "Jewish, Ukrainian, Belarusian or German production" (22). He justifies this approach partly on the grounds that his intention is not "to provide a broad panorama of all phenomena that could be termed performances occurring throughout history in lands that have been or are today recognized as Polish" (22) and also that it was his "intention not to include those works of artists working in Poland and the Polish context who aimed at creating their own culture" (22). Moreover, regarding Jewish theatre, he says "I would consider including their work in the history of performing Poland as an unfair act of appropriation" (22).

However, the problem with Kosiński's approach, despite all his caveats in the introduction, is that it effectively supports rather than questions the nineteenth-century romantic notion of a unified Polish identity. Thus, despite Poland's long history of mixed identities, such as the Polish-Lithuanian Commonwealth, its various linguistic and ethnic groups, its regional differences and local peasant cultures, its long Jewish cultural tradition, its changing borders with Belarus and Germany, and its history of regional alliances, fractures, dislocations, displacements, and repatriations, Kosiński wants to present an ethnically clean version of Polish theatre. It does not help to have the increasingly nationalistic and misogynistic tendencies of the current Polish government as the backdrop to the publication of his book. Without that political context, one might be more magnanimous in appreciating Kosiński's approach. But in the present political circumstances, one feels that the assertion of a homogenous Polish identity serves to substantiate rather than undermine the nationalist rhetoric of the Law and Order party. Thus, the question should be asked: why assert this version of identity in the twenty-first century when scholars such as Benedict Anderson, Ernest Gellner, Eric Hobsbawm, Anthony Smith, and Tomasz Kamusella have so thoroughly deconstructed it? 


\section{Bibliography}

Kosiński, Dariusz. Performing Poland: Rethinking Histories and Theatres. Translated by Paul Vickers. Aberystwyth: Instytut Teatralny and Performance Research Books, 2019.

\section{Abstract}

\section{Performing "Polishness"}

This article is a review of Dariusz Kosiński's Performing Poland: Rethinking Histories and Theatres (Aberystwyth 2019). The author points out that the book is an attempt at introducing several centuries of Polish theatre and performance to an international reader. It is divided into five sections which overlap chronologically, altogether creating a comprehensive presentation of Polish theatre. These sections are: theatre of festivities, theatre of fundamental questions, national theatre, political theatre, and theatre of the cultural metropolis. The author, however, draws attention to a problematic issue in Kosiński's approach. Throughout the book he emphasizes the role of theatre and performance in asserting Polish national identity while ignoring the complex, multi-faceted character of any national identity.

\section{Keywords}

Polish theatre, national theatre, national identity, performing identity

\section{Abstrakt}

\section{Performowanie "polskości"}

Artykuł jest recenzją książki Dariusza Kosińskiego Performing Poland: Rethinking Histories and Theatres (Aberystwyth 2019). Autor podkreśla, że jest to próba przedstawienia kilku wieków historii polskiego teatru i performansu międzynarodowej publiczności. Książka została podzielona na pięć części, które zachodzą na siebie chronologicznie i składają się na syntetyczny obraz polskiego teatru: teatr świąt, teatr pytań fundamentalnych, teatr narodowy, teatr polityczny i teatr kulturalnego miasta. Recenzent zwraca uwagę na problematyczny aspekt zaproponowanego w książce ujęcia. Kosiński, podkreślając rolę teatru i performansu w utwierdzaniu polskiej tożsamości narodowej, nie bierze pod uwagę skomplikowanego i wieloaspektowego charakteru każdej tożsamości narodowej.

\section{Słowa kluczowe}

teatr polski, teatr narodowy, tożsamość narodowa, performowanie tożsamości

\section{S. E. WILMER}

Professor Emeritus at Trinity College Dublin, where he has been Head of the School of Drama, Film and Music. He has been a Visiting Professor at Stanford University and the University of California at Berkeley. He is also a playwright. His research interests include: historiography of national theatres, staging and performing identities, philosophical aspects of theatre and drama. 